Article

\title{
New Evidence on the Information and Predictive Content of the Baltic Dry Index
}

\author{
Nicholas Apergis $^{1, *}$ and James E. Payne ${ }^{2}$
}

1 Department of Banking and Financial Management, University of Piraeus, 80 Karaoli \& Dimitriou, Piraeus 18534, Greece

2 Department of Economics and Finance, University of New Orleans, 2000 Lakeshore Drive, New Orleans, LA 70148, USA; E-Mail: jepayne@uno.edu

* Author to whom correspondence should be addressed; E-Mail: napergis@unipi.gr; Tel.: +30-210-414-2429; Fax: +30-210-414-2341.

Received: 13 May 2013; in revised form: 15 July 2013 / Accepted: 16 July 2013 /

Published: 24 July 2013

\begin{abstract}
This empirical study analyzes the information and predictive content of the Baltic Dry Index (BDI) with respect to a range of financial assets and the macroeconomy. By using panel methodological approaches and daily data spanning the period 1985-2012, the empirical analysis documents the joint predictability capacity of the BDI for both financial assets and industrial production. The results reveal the role of the BDI in predicting the future course of the real economy, yielding a link between financial asset markets and the macroeconomy.
\end{abstract}

Keywords: Baltic Dry Index; asset markets; macroeconomy; panel data

JEL Codes: C23; G11; G12; G13; E23

\section{Introduction}

The ability to track and even anticipate economic activity has been an ongoing endeavor of economic researchers. The debate over the use of a single or collection of leading indicators has been long standing (see Stock and Watson [1,2]; Cecchetti et al. [3]; Camba-Mendez et al. [4], among others). In addition to the use of leading indicators, the predictive content of financial assets in relation to economic activities has also been extensively examined (see Fama [5]; Cochrane [6]; Restoy and 
Rockinger [7]; Boldrin et al. [8]; Estrella et al. [9]; Vassalou [10]; Duarte et al. [11]; Hong et al. [12]; Clements and Galvao [13]; Cooper and Priestley [14]; Marcellino and Schumacher [15], amongst others). Theoretically, changes in industrial production lead to changes in activity, employment and liquidity in the economy. Therefore, the economy experiences changes in cash availability and, thus, there is a better chance this to be invested or disinvested in the stock market, yielding changes in stock prices.

Moreover, oil prices have been a recurrent topic in terms of representing the impact of supply shocks in propagating cyclical fluctuations (see Hamilton [16]; Killian [17], amongst others). In a very recent paper, Kilian and Park [18] show that the reaction of U.S. real stock returns to oil price shocks differs significantly. According to the authors, this differentiation is primarily due to the nature of shocks hidden behind oil price changes.

However, an area of inquiry not explicitly considered has been the supply (chain) structure associated with the shipping industry. In particular, the structure of the shipping industry is relatively predictable with any changes in shipping costs due largely to changes in worldwide demand for raw materials (Stopford [19]). Specifically, the Baltic Dry Index (BDI) tracks the cost of shipping commodities, such as coal, iron ore, steel, cement, and grain, around the world. Information is available since 1744 when merchants and ships' captains at the Virginia and Baltic Coffee House in London's Threadneedle Street were exchanging views on the course of their business. In 1985, the Baltic Exchange launched the BDI as a primary indicator of shipment rates.

This index can be used as an overall economic indicator as it reflects the direction of end-use prices for goods that use the raw materials that are shipped in dry bulk. The BDI is especially relevant for the trade of the Less Developed Countries (LDCs) whose exports are mainly made up of primary goods, with the majority of them relying on bulk carriers for international transportation. In this respect, the BDI reflects important components of the cost of trade, rendering a negative effect on the LDCs trading activities. The close association between the cost of shipping raw materials and the production of intermediate and final goods, has led some analysts and researchers to conclude that the demand for commodities and, therefore, economic activity, is reflected by movements in the BDI. In other words, the association between the BDI and stock markets comes in an indirect manner, since the BDI reflects changes in economic activity, (i.e., aggregate demand and supply conditions), which, in turn, affects the course of the international stock markets. The link between economic activity and financial markets has been extensively stressed in the empirical and theoretical literature. At the same time, changes in the BDI are linked to changes in the prices of commodities, since the BDI is sensitive to developments in the demand for raw materials and global trade, while the behavior of commodity prices varies over the business cycle.

It is assumed that when the BDI rises, the increase reflects a stronger demand for commodities, as producers are purchasing more materials to accommodate the growth in production while a downward trend in the BDI implies that producers face insufficient consumer demand, with firms curtailing production as a result. Some analysts consider the BDI to be a useful indicator, especially when looking for signs of economic recovery, on the grounds that the index provides real-time updates vis-à-vis traditional economic indicators. As a matter of fact, the BDI could also reflect some speculative movements, since there are futures contracts on BDI (albeit with small volumes) and the underlying freight market may also reflect the speculative actions of market participants. One of the very limited 
papers that consider a shipping index as a leading indicator to predict a number of economic and financial variables is that of Bashki et al. [20] who argue that this shipping indicator has strong predictability in terms of commodity assets and low predictability in terms of stock market assets.

Given the limited literature on new leading indicators that could be used not only to predict the future course of economic growth, but also a number of asset prices and, thus, assist international portfolio investors to form more rational investment strategies, the appropriate research question this study investigates is the quality of the information and predictive content of the BDI as a leading indicator with respect to a number of asset markets and the macroeconomy as well. In terms of the asset markets, this empirical endeavor investigates whether changes in the BDI could be fully, partially or not all reflected in asset prices, thus, lending support or not to the Efficient Market Hypothesis (EMH). The study is largely exploratory in nature by utilizing daily data for G7 countries within a panel framework to infer the long-run equilibrium relationship between the BDI with both the financial asset markets and macroeconomy along with the short-run and long-run causal dynamics. Furthermore, the out-of-sample forecasting performance of the BDI with respect to the financial asset markets and the macroeconomy is presented as well. Our work builds on the work of Alizadeh and Muradoglu [21], but our empirical findings are not consistent with theirs in the sense that the BDI displays strong predictability performance, a fact that violates the gradual diffusion of information from shipping indicators to investors across asset markets. Our work is different from theirs in a sense that makes use of not only commodity and stock markets but also of short- and long-term bond markets. The panel data methodology generates empirical findings that are consistent with the rapid dissemination of shipping information to investors across asset markets. Moreover, this study also extends the analysis to the G7 stock markets through a panel framework. No prior study in the field of shipping indicators has considered a panel data methodology framework. Finally, we use shipping indexes not only along with oil prices, but also with indexes that capture the world market activity and, still the results exemplify the superiority of shipping indexes with reference to the predictability of asset markets. Section 2 discusses the data and the empirical results with concluding remarks given in Section 3.

\section{Data and Results}

\subsection{Data and Their Integration Properties}

We collect daily data for the G7 countries: Canada, France, Germany, Italy, Japan, U.K., and the U.S. with respect to stock market returns $\left(\mathrm{AP}^{\mathrm{STK}}\right)$, interest rates on short-term bonds $\left(\mathrm{AP}^{\mathrm{STB}}\right)$, interest rates on long-term bonds $\left(\mathrm{AP}^{\mathrm{LTB}}\right)$, commodity prices $\left(\mathrm{AP}^{\mathrm{COM}}\right)$ and oil prices $(\mathrm{OP})$, and monthly data on industrial production (IP) over the period 1985 to 2012. Datastream provides the data on stock market returns, interest rates on short-term and long-term bonds, industrial production, and oil prices while data on commodity prices, the Baltic Dry Index (BDI), and the global stock market index, MSCI World Index (MSCI) are obtained from Bloomberg. Data are seasonally adjusted with all variables, except interest rates, in natural logarithms. Given the monthly nature of the industrial production indices and the estimation requirements of Equation (2), the BDI daily data are transformed into monthly data by selecting the last day of the relevant month. Details on the variables are shown in the 
data appendix. The in-sample estimation period is 1985:1 to 2011:365 with the out-of-sample period for forecasting, 2012:1 to 2012:365.

The analysis begins with an examination of the unit root properties of the respective variables via panel unit root tests to determine the order of integration. Several panel unit root tests are undertaken to ascertain the robustness of the results. These panel unit root tests include Levin and Lin [22], Harris and Tzavalis [23], Maddala and $\mathrm{Wu}$ [24], and Breitung [25]. For each of these tests the null hypothesis is the presence of a unit root. The results in Table 1 show that the null hypothesis that the levels of all three variables contain a unit root is accepted at the $1 \%$ significant level across the panel unit root tests. By contrast, when the panel unit root tests are applied on the first differences of the variables, the unit root hypothesis is rejected.

However, the three indicator variables, BDI, the MSCI, and oil prices, are, first, tested using the augmented Dickey-Fuller [26] unit root test. At the 5\% significance level, the results indicate acceptance of the null hypothesis of a unit root in levels. When first differences are tested, the null hypothesis of a unit root is rejected. We also applied the DF-WS (weighted symmetric) test proposed by Park and Fuller [27] and the DF-GLS (generalized least squares) test proposed by Elliott et al. [28]. These results are also reported in Table 1 which indicates the variables are integrated of order one.

Table 1. Unit root tests.

\begin{tabular}{|c|c|c|c|c|c|}
\hline Variables & $\mathbf{L L}$ & F-ADF & F-PP & HT & Breit \\
\hline \multirow[t]{2}{*}{$\mathrm{AP}^{\mathrm{STK}}$} & -1.36 & 16.52 & 14.35 & -1.25 & -1.25 \\
\hline & $-9.71 *$ & $163.44 *$ & $146.51 *$ & $-8.49 *$ & $-9.34 *$ \\
\hline $\mathrm{AP}^{\mathrm{STB}}$ & -1.19 & 14.31 & 13.29 & -1.15 & -1.30 \\
\hline$\Delta \mathrm{AP}^{\mathrm{STB}}$ & $-8.54 *$ & $172.36 *$ & $137.18 *$ & $-8.36 *$ & $-9.71 *$ \\
\hline $\mathrm{AP}^{\mathrm{LTB}}$ & -1.26 & 13.59 & 14.28 & -1.16 & -1.22 \\
\hline$\Delta \mathrm{AP}^{\mathrm{LTB}}$ & $-9.38 *$ & $178.48 *$ & $175.28 *$ & $-9.55 *$ & $-9.90 *$ \\
\hline $\mathrm{AP}^{\mathrm{COM}}$ & -1.29 & 14.52 & 16.33 & -1.07 & -1.14 \\
\hline$\Delta \mathrm{AP}^{\mathrm{COM}}$ & $-9.36 *$ & $165.73 *$ & $152.39 *$ & $-9.47 *$ & $-9.73 *$ \\
\hline IP & -1.05 & 11.06 & 12.31 & -1.03 & -1.28 \\
\hline \multirow[t]{2}{*}{$\Delta \mathrm{IP}$} & $-9.74 *$ & $150.38 *$ & $148.46 *$ & $-8.74 *$ & $-7.94 *$ \\
\hline & ADF & DF-WS & DF-GLS & & \\
\hline BDI & -1.14 & -1.23 & -1.25 & & \\
\hline$\Delta \mathrm{BDI}$ & $-7.82 *$ & $-8.48 *$ & $-7.62^{*}$ & & \\
\hline MSCI & -1.29 & -1.11 & -1.24 & & \\
\hline$\triangle \mathrm{MSCI}$ & $-8.39 *$ & $-7.74 *$ & $-8.83^{*}$ & & \\
\hline OP & -1.25 & -1.27 & -1.20 & & \\
\hline$\Delta \mathrm{OP}$ & $-7.83 *$ & $-9.37 *$ & $-8.39 *$ & & \\
\hline
\end{tabular}

Notes: $\Delta$ denotes first differences; LL denotes the Levin and Lin test; F-ADF and F-PP denotes the Maddala and Wu test; HT denotes the Harris and Tzavalis test; Breit denotes the Breitung test; * accepts the null hypothesis of stationarity at the $1 \%$ level.

\subsection{Long-Run Model and Panel Cointegration}

Two specifications of the long-run equilibrium are postulated to explore the role of the BDI on financial asset markets and the macroeconomy given by Equations (1) and (2). 


$$
\mathrm{AP}_{\mathrm{it}}=\alpha_{\mathrm{i}}+\delta_{\mathrm{i}} \mathrm{t}+\mathrm{a}_{1} \mathrm{BDI}_{\mathrm{t}}+\varepsilon_{\mathrm{it}}
$$

and

$$
\mathrm{IP}_{\mathrm{jt}}=\alpha_{\mathrm{i}}+\delta_{\mathrm{i}} \mathrm{t}+\mathrm{a}_{1} \mathrm{BDI}_{\mathrm{t}}+\eta_{\mathrm{jt}}
$$

where $\mathrm{i}=1, \ldots, \mathrm{N}$ for each financial asset in the panel $\left(\mathrm{AP}^{\mathrm{STK}}, \mathrm{AP}^{\mathrm{STB}}, \mathrm{AP}^{\mathrm{LTB}}, \mathrm{AP}^{\mathrm{COM}}\right), \mathrm{j}=1, \ldots, \mathrm{M}$ for IP representing the macroeconomy in the panel, and $\mathrm{t}=1, \ldots, \mathrm{T}$ refers to the time period. The parameters $\alpha_{\mathrm{i}}$ and $\delta_{\mathrm{i}}$ allow for the possibility of market-specific fixed effects and deterministic trends, respectively. Finally, $\varepsilon_{i t}$ and $\eta_{i t}$ denote the estimated residuals, which represent deviations from the long-run relationship.

To determine whether a long-run relationship exists between financial assets, industrial production, and the BDI we utilize the methodology of Pedroni's [29] panel cointegration test. This cointegration methodology tests for a common stochastic trend in the panel under the null hypothesis of no cointegration. The panel tests are based on the within dimension approach (panel v, panel $\rho$, panel PP, and panel ADF statistics) which pools the autoregressive coefficients across different countries for the unit root tests on the estimated residuals, taking into account common time factors and heterogeneity across countries. The group mean panel tests are based on the between dimension approach (group $\rho$, group PP, and group ADF statistics) which compute averages of the individual autoregressive coefficients associated with the unit root tests of the residuals for each country in the panel. Table 2 reports the results of the panel cointegration test (the Akaike information criterion with individual intercepts and trends is used to determine the lag length). The null hypothesis of no cointegration is rejected in favor of a long-run relationship between financial asset prices (and across individual asset markets) and the BDI, as well as between industrial production and the BDI.

\begin{tabular}{|c|c|c|c|}
\hline \multicolumn{4}{|l|}{ Panel A: AP ${ }^{\text {STK}}$-BDI } \\
\hline Panel Tests: & \multicolumn{3}{|c|}{ Group Mean Panel Tests: } \\
\hline Panel v-statistic & $56.44952 *$ & Group $\rho$-statistic & $-57.35286 *$ \\
\hline Panel $\rho$-statistic & $-54.09539 *$ & Group PP-statistic & $-57.48095 *$ \\
\hline Panel PP-statistic & $-54.43875 *$ & Group ADF-statistic & $-12.27308 *$ \\
\hline Panel ADF-statistic & $-12.74976 *$ & & \\
\hline \multicolumn{4}{|l|}{ Panel B: AP $^{\text {STB }}$-BDI } \\
\hline Panel Tests: & & Mean Panel Tests: & \\
\hline Panel v-statistic & $57.96732 *$ & Group $\rho$-statistic & $-57.83485 *$ \\
\hline Panel $\rho$-statistic & $-56.92985 *$ & Group PP-statistic & $-58.75298 *$ \\
\hline Panel PP-statistic & $-56.74398 *$ & Group ADF-statistic & $-12.50084 *$ \\
\hline Panel ADF-statistic & $-11.76439 *$ & & \\
\hline \multicolumn{4}{|l|}{ Panel C: AP $^{\mathrm{LTB}}$-BDI } \\
\hline Panel Tests: & \multicolumn{3}{|c|}{ Group Mean Panel Tests: } \\
\hline Panel v-statistic & $56.57549 *$ & Group $\rho$-statistic & $-55.72306 *$ \\
\hline Panel $\rho$-statistic & $-57.28944 *$ & Group PP-statistic & $-58.82745 *$ \\
\hline Panel PP-statistic & $-57.89075 *$ & Group ADF-statistic & $-12.93284 *$ \\
\hline Panel ADF-statistic & $-12.32486 *$ & & \\
\hline
\end{tabular}

Table 2. Panel cointegration tests. 
Table 2. Cont.

\begin{tabular}{|c|c|c|c|}
\hline \multicolumn{4}{|l|}{ Panel D: AP $^{\mathrm{COM}}$-BDI } \\
\hline Panel Tests: & & Group Mean Panel Tests: & \\
\hline Panel v-statistic & $57.84562 *$ & Group $\rho$-statistic & $-56.22375 *$ \\
\hline Panel $\rho$-statistic & $-56.63762 *$ & Group PP-statistic & $-56.96574 *$ \\
\hline Panel PP-statistic & $-56.09894 *$ & Group ADF-statistic & $-11.58942 *$ \\
\hline Panel ADF-statistic & $-11.32387 *$ & & \\
\hline \multicolumn{4}{|l|}{ Panel E: IP-BDI } \\
\hline Panel Tests: & & Group Mean Panel Tests: & \\
\hline Panel v-statistic & $53.42573 *$ & Group $\rho$-statistic & $-52.93287 *$ \\
\hline Panel $\rho$-statistic & $-52.98956 *$ & Group PP-statistic & $-52.79640 *$ \\
\hline Panel PP-statistic & $-52.67860 *$ & Group ADF-statistic & $-8.62583 *$ \\
\hline Panel ADF-statistic & $-9.63297 *$ & & \\
\hline
\end{tabular}

Given the presence of a long-run equilibrium, we follow Pedroni [30,31] in using the methodology of fully-modified ordinary least squares (FMOLS) to estimate the long-run parameter estimates. Table 3 shows that the impact of the BDI on financial asset prices and industrial production is positive and statistically significant at the 1\% level, implying that a higher BDI leads to both higher financial asset prices and industrial production. Our results are consistent with those reached by French et al. [32] and Schwert [33] who claim that in equilibrium (i.e., in cointegration terms) the relationship is expected to be positive. Moreover, the adjusted $\mathrm{R}^{2}$ is relatively high, compared to those reported by other studies of predictors for stock returns (Campbell and Thompson [34]; Goyal and Welch [35]). In terms of industrial production, our empirical findings are consistent with those presented in the literature regarding the nexus between the real economy and the financial sector (Fama [5]; Cochrane [6]; Vassalou [10]; Rangvid [36]). Finally, the results are also consistent with the literature regarding the tendency of commodity prices to vary over the business cycle (Bessembinder and Chan [37] and Gorton et al. [38]).

Table 3. FMOLS (fully-modified ordinary least squares) long-run estimates.

\begin{tabular}{cccc}
\hline Variable & $\mathbf{a}_{\mathbf{1}}$ & $\boldsymbol{p}$-value & Adjusted-R $^{2}$ \\
\hline $\mathrm{AP}^{\mathrm{STK}}$ & 0.148 & {$[0.00]^{*}$} & 0.63 \\
$\mathrm{AP}^{\mathrm{STB}}$ & 0.081 & {$[0.01]^{*}$} & 0.52 \\
$\mathrm{AP}^{\mathrm{LTB}}$ & 0.104 & {$[0.00]^{*}$} & 0.57 \\
$\mathrm{AP}^{\mathrm{COM}}$ & 0.119 & {$[0.01]^{*}$} & 0.45 \\
$\mathrm{IP}$ & 0.175 & {$[0.00]^{*}$} & 0.66 \\
\hline
\end{tabular}

Notes: $\mathrm{a}_{1}$ is the coefficient for BDI; $\mathrm{p}$-value is the probability value attached the $\mathrm{a}_{1}$ coefficient estimate; and adjusted $\mathrm{R}^{2}$ is the adjusted coefficient of determination. Probability values are in brackets with the $1 \%$ significance level denoted by “*”. 


\subsection{Panel Causality Results}

Next, we estimate a panel error correction model to infer both the short-run and long-run causality between the respective financial asset markets, industrial production, and the BDI. Short-run causality is denoted by Wald F-tests on the lagged coefficients of the first differences of the respective variables while long-run causality is given by the statistical significance of the error correction term (ECT). Table 4 reports the causality results in which the BDI appears to Granger-cause both the financial asset prices and industrial production in both the short-run and long-run, while a feedback effect exists only in the case of industrial production. Hence, the causal dynamics reveal that the BDI contains properties of a leading indicator. A rationale for this significant causal relationship could be that the BDI is indirectly linked to the performance of the financial asset markets through its impact on the real economy.

Table 4. Panel causality test results.

\begin{tabular}{|c|c|c|c|c|}
\hline \multicolumn{5}{|c|}{ Panel A: AP ${ }^{\text {STK}}$-BDI (7 lags) } \\
\hline & \multicolumn{2}{|c|}{ Short-run } & \multirow{2}{*}{$\begin{array}{c}\text { Long-Run } \\
\text { ECT } \\
-0.168\end{array}$} & \multirow{2}{*}{$\begin{array}{c}\text { Granger-Causality } \\
\mathrm{BDI} \rightarrow \mathrm{AP}^{\mathrm{STK}}(\mathrm{SR} \text { and LR })\end{array}$} \\
\hline$\Delta \mathrm{AP}^{\mathrm{STK}}$ & $\begin{array}{c}\Delta \mathrm{AP}^{\mathrm{STK}} \\
--- \\
{[0.00]^{*}}\end{array}$ & $\begin{array}{c}\Delta \mathrm{BDI} \\
64.73 \\
{[0.00]^{*}}\end{array}$ & & \\
\hline$\Delta \mathrm{BDI}$ & $\begin{array}{c}1.19 \\
{[0.46]}\end{array}$ & --- & $\begin{array}{r}-0.041 \\
{[0.23]}\end{array}$ & \\
\hline \multicolumn{5}{|c|}{ Panel B: AP ${ }^{\mathrm{STB}}$-BDI (7 lags) } \\
\hline & \multicolumn{2}{|c|}{ Short-run } & Long-Run & Granger-Causality \\
\hline$\Delta \mathrm{AP}^{\mathrm{STB}}$ & $\begin{array}{c}\Delta \mathrm{AP}^{\mathrm{STB}} \\
---\end{array}$ & $\begin{array}{c}\Delta \text { BDI } \\
48.92 \\
{[0.00]^{*}}\end{array}$ & $\begin{array}{c}\text { ECT } \\
-0.137 \\
{[0.00] *}\end{array}$ & $\mathrm{BDI} \rightarrow \mathrm{AP}^{\mathrm{STB}}(\mathrm{SR} / \mathrm{LR})$ \\
\hline$\Delta \mathrm{BDI}$ & $\begin{array}{c}0.35 \\
{[0.69]}\end{array}$ & --- & $\begin{array}{l}-0.042 \\
{[0.57]}\end{array}$ & \\
\hline \multicolumn{5}{|c|}{ Panel C: AP ${ }^{\text {LTB }}$-BDI (6 lags) } \\
\hline & \multicolumn{2}{|c|}{ Short-run } & Long-Run & Granger-Causality \\
\hline$\Delta \mathrm{AP} \mathrm{P}^{\mathrm{LTB}}$ & $\begin{array}{c}\Delta \mathrm{AP}^{\mathrm{LTB}} \\
---\end{array}$ & $\begin{array}{c}\Delta \mathrm{BDI} \\
58.82 \\
{[0.00]^{*}}\end{array}$ & $\begin{array}{c}\text { ECT } \\
-0.149 \\
{[0.00]^{*}}\end{array}$ & $\mathrm{BDI} \rightarrow \mathrm{AP}^{\mathrm{LTB}}(\mathrm{SR} / \mathrm{LR})$ \\
\hline$\Delta \mathrm{BDI}$ & $\begin{array}{c}0.41 \\
{[0.72]}\end{array}$ & --- & $\begin{array}{l}-0.025 \\
{[0.68]}\end{array}$ & \\
\hline \multicolumn{5}{|c|}{ Panel D: AP ${ }^{\mathrm{COM}}$-BDI (6 lags) } \\
\hline & \multicolumn{2}{|c|}{ Short-run } & Long-Run & Granger-Causality \\
\hline$\Delta \mathrm{AP}^{\mathrm{COM}}$ & $\begin{array}{c}\Delta \mathrm{AP}^{\mathrm{COM}} \\
---\end{array}$ & $\begin{array}{c}\Delta \text { BDI } \\
62.33 \\
{[0.00]^{*}}\end{array}$ & $\begin{array}{c}\text { ECT } \\
-0.164 \\
{[0.00]^{*}}\end{array}$ & $\mathrm{BDI} \rightarrow \mathrm{AP}^{\mathrm{COM}}(\mathrm{SR} / \mathrm{LR})$ \\
\hline$\Delta \mathrm{BDI}$ & $\begin{array}{c}0.55 \\
{[0.68]}\end{array}$ & --- & $\begin{array}{c}-0.021 \\
{[0.50]}\end{array}$ & \\
\hline
\end{tabular}


Table 4. Cont.

\begin{tabular}{|c|c|c|c|c|}
\hline \multicolumn{5}{|c|}{ Panel E: IP-BDI (6 lags) } \\
\hline & \multicolumn{2}{|c|}{ Short-run } & Long-Run & Granger-Causality \\
\hline & $\Delta \mathrm{IP}$ & $\Delta \mathrm{BDI}$ & ECT & $\mathrm{BDI} \rightarrow \mathrm{IP}(\mathrm{SR} / \mathrm{LR})$ \\
\hline$\Delta \mathrm{IP}$ & --- & $\begin{array}{c}52.07 \\
{[0.00]^{*}}\end{array}$ & $\begin{array}{c}-0.144 \\
{[0.00] *}\end{array}$ & \\
\hline$\Delta \mathrm{BDI}$ & $\begin{array}{c}42.06 \\
{[0.00] *}\end{array}$ & --- & $\begin{array}{c}-0.124 \\
{[0.00] *}\end{array}$ & \\
\hline
\end{tabular}

Notes: Wald F-statistics reported with respect to short-run changes in the independent variables; ECT represents the coefficient of the error correction term; Probability values are in brackets with the $1 \%$ significance level denoted by “*”; SR represents the short-run and LR the long-run.

Moreover, the negative sign associated with the parameter estimates for the error correction terms represents the speed of the adjustment of financial asset prices or industrial production towards long-run equilibrium in response to shocks. The larger the value of this parameter estimate, the stronger is the response of the variable to the previous period's deviation from long-run equilibrium. All error correction terms display a relatively high speed of adjustment toward long-run equilibrium with the speed of adjustment as follows: $-0.168\left(\mathrm{AP}^{\mathrm{STK}}\right),-0.137\left(\mathrm{AP}^{\mathrm{STB}}\right),-0.149\left(\mathrm{AP}^{\mathrm{LTB}}\right),-0.164$ $\left(\mathrm{AP}^{\mathrm{COM}}\right)$ and -0.144 (IP).

\subsection{Robustness Tests: Alternative Indicators}

We also address the merit of the BDI vis-à-vis a number of alternative indicators. Such alternative indicators are the MSCI World Index and oil prices. Both the MSCI World Index and oil prices (in the same manner as the BDI) reflect the expectations of investors and market operators regarding the performance of firms and the economy in general. To the extent that these expectations are largely correct, these indices could be also used to gauge future economic activity. The former index has been used in the literature by Harvey [39,40], while the latter has been extensively recommended in the literature (Jones and Kaul [41]; Ang and Bekaert [42]; Sorensen [43]; Hjalmarsson [44]). However, the employment of oil prices as a leading indicator has encountered a number of problems, such as the fact that these prices are driven by both demand and supply shocks which tend to affect in a different way the economic activity, while it generates variables omission bias in production estimations, since oil is not the only input of production and neglecting other related inputs, i.e., iron ore, bauxite and alumina, and copper, leads to biased estimates.

Thus, the alternative long-run specifications incorporating the MSCI are given as follows in Equations (3) and (4):

$$
\mathrm{AP}_{\mathrm{it}}=\alpha_{\mathrm{i}}+\delta_{\mathrm{i}} \mathrm{t}+\mathrm{a}_{1} \mathrm{BDI}_{\mathrm{t}}+\mathrm{a}_{2} \mathrm{MSCI}_{\mathrm{t}}+\varepsilon_{\mathrm{it}}
$$

and

$$
\mathrm{IP}_{\mathrm{jt}}=\alpha_{\mathrm{i}}+\delta_{\mathrm{i}} \mathrm{t}+\mathrm{a}_{1} \mathrm{BDI}_{\mathrm{t}}+\mathrm{a}_{2} \mathrm{MSCI}_{\mathrm{t}}+\eta_{\mathrm{jt}}
$$


In addition, the long-run specifications incorporating oil prices are noted as follows in Equations (5) and (6):

$$
\mathrm{AP}_{\mathrm{it}}=\alpha_{\mathrm{i}}+\delta_{\mathrm{i}} \mathrm{t}+\mathrm{a}_{1} \mathrm{BDI}_{\mathrm{t}}+\mathrm{a}_{2} \mathrm{OP}_{\mathrm{t}}+\varepsilon_{\mathrm{it}}
$$

and

$$
\mathrm{IP}_{\mathrm{jt}}=\alpha_{\mathrm{i}}+\delta_{\mathrm{i}} \mathrm{t}+\mathrm{a}_{1} \mathrm{BDI}_{\mathrm{t}}+\mathrm{a}_{2} \mathrm{OP}_{\mathrm{t}}+\eta_{\mathrm{jt}}
$$

As in Equations (1) and (2), we are interested in the statistical significance of the $a_{1}$ coefficient, in light of the presence of the alternative indicators. The new panel cointegration test results incorporating the above specifications are reported in Table 5. The results reject the null hypothesis of no cointegration across all specifications.

\begin{tabular}{|c|c|c|c|}
\hline \multicolumn{4}{|c|}{ Panel A: AP ${ }^{\text {STK}}$-BDI-MSCI } \\
\hline Panel Tests: & \multicolumn{3}{|c|}{ Group Mean Panel Tests: } \\
\hline Panel v-statistic & $42.63286 *$ & Group $\rho$-statistic & $-41.82673 *$ \\
\hline Panel $\rho$-statistic & $-43.95738 *$ & Group PP-statistic & $-41.50842 *$ \\
\hline Panel PP-statistic & $-43.42387 *$ & Group ADF-statistic & $-7.62749 *$ \\
\hline Panel ADF-statistic & $-8.82086 *$ & & \\
\hline \multicolumn{4}{|c|}{ Panel B: AP ${ }^{\mathrm{STK}}$-BDI-OP } \\
\hline Panel Tests: & \multicolumn{3}{|c|}{ Mean Panel Tests: } \\
\hline Panel v-statistic & $45.52984 *$ & Group $\rho$-statistic & $-44.47389 *$ \\
\hline Panel $\rho$-statistic & $-44.08942 *$ & Group PP-statistic & $-45.50908 *$ \\
\hline Panel PP-statistic & $-44.52896 *$ & Group ADF-statistic & $-8.63264 *$ \\
\hline Panel ADF-statistic & $-8.66420 *$ & & \\
\hline \multicolumn{4}{|c|}{ Panel C: AP ${ }^{\text {STB}}$-BDI-MSCI } \\
\hline Panel Tests: & \multicolumn{3}{|c|}{ Group Mean Panel Tests: } \\
\hline Panel v-statistic & $40.38934 *$ & Group $\rho$-statistic & $-40.82764 *$ \\
\hline Panel $\rho$-statistic & $-41.90893 *$ & Group PP-statistic & $-39.65259 *$ \\
\hline Panel PP-statistic & $-41.67328 *$ & Group ADF-statistic & $-6.58276^{*}$ \\
\hline Panel ADF-statistic & $-6.96318 *$ & & \\
\hline \multicolumn{4}{|c|}{ Panel D: AP ${ }^{\text {STB }}$-BDI-OP } \\
\hline Panel Tests: & \multicolumn{3}{|c|}{ Group Mean Panel Tests: } \\
\hline Panel v-statistic & $41.32437 *$ & Group $\rho$-statistic & $-40.82569 *$ \\
\hline Panel $\rho$-statistic & $-42.72785 *$ & Group PP-statistic & $-40.42487 *$ \\
\hline Panel PP-statistic & $-42.62674 *$ & Group ADF-statistic & $-6.72487 *$ \\
\hline Panel ADF-statistic & $-6.42684 *$ & & \\
\hline \multicolumn{4}{|c|}{ Panel E: AP ${ }^{\text {LTB }}$-BDI-MSCI } \\
\hline Panel Tests: & \multicolumn{3}{|c|}{ Group Mean Panel Tests: } \\
\hline Panel v-statistic & $39.82376 *$ & Group $\rho$-statistic & $-38.62364 *$ \\
\hline Panel $\rho$-statistic & $-40.72365 *$ & Group PP-statistic & $-39.72436 *$ \\
\hline Panel PP-statistic & $-40.62438 *$ & Group ADF-statistic & $-6.50894 *$ \\
\hline Panel ADF-statistic & $-6.61327 *$ & & \\
\hline
\end{tabular}

Table 5. Extended panel cointegration tests. 
Table 5. Cont.

\begin{tabular}{|c|c|c|c|}
\hline \multicolumn{4}{|c|}{ Panel F: AP ${ }^{\text {LTB }}$-BDI-OP } \\
\hline Panel Tests: & \multicolumn{3}{|c|}{ Group Mean Panel Tests: } \\
\hline Panel v-statistic & $40.47325 *$ & Group $\rho$-statistic & $-40.62548 *$ \\
\hline Panel $\rho$-statistic & $-41.22586 *$ & Group PP-statistic & $-42.32546 *$ \\
\hline Panel PP-statistic & $-41.72674 *$ & Group ADF-statistic & $-7.76409 *$ \\
\hline Panel ADF-statistic & $-6.52547 *$ & & \\
\hline \multicolumn{4}{|c|}{ Panel G: AP ${ }^{\text {COM}}$-BDI-MSCI } \\
\hline Panel Tests: & \multicolumn{3}{|c|}{ Group Mean Panel Tests: } \\
\hline Panel v-statistic & $42.33261 *$ & Group $\rho$-statistic & $-41.41436 *$ \\
\hline Panel $\rho$-statistic & $-41.14756 *$ & Group PP-statistic & $-41.20415 *$ \\
\hline Panel PP-statistic & $-41.90855 *$ & Group ADF-statistic & $-6.52008 *$ \\
\hline Panel ADF-statistic & $-6.68952 *$ & & \\
\hline \multicolumn{4}{|c|}{ Panel H: AP ${ }^{\mathrm{COM}}$-BDI-OP } \\
\hline Panel Tests: & \multicolumn{3}{|c|}{ Group Mean Panel Tests: } \\
\hline Panel v-statistic & $40.49956 *$ & Group $\rho$-statistic & $-40.35465 *$ \\
\hline Panel $\rho$-statistic & $-41.71135 *$ & Group PP-statistic & $-41.32365 *$ \\
\hline Panel PP-statistic & $-41.60908 *$ & Group ADF-statistic & $-6.59089 *$ \\
\hline Panel ADF-statistic & $-6.82546 *$ & & \\
\hline \multicolumn{4}{|c|}{ Panel I: IP-BDI-MSCI } \\
\hline Panel Tests: & \multicolumn{3}{|c|}{ Group Mean Panel Tests: } \\
\hline Panel v-statistic & $43.56008 *$ & Group $\rho$-statistic & $-43.62541 *$ \\
\hline Panel $\rho$-statistic & $-41.41136 *$ & Group PP-statistic & $-43.88325 *$ \\
\hline Panel PP-statistic & $-41.90671 *$ & Group ADF-statistic & $-7.83073 *$ \\
\hline Panel ADF-statistic & $-7.80665 *$ & & \\
\hline \multicolumn{4}{|l|}{ Panel J: IP-BDI-OP } \\
\hline Panel Tests: & \multicolumn{3}{|c|}{ Group Mean Panel Tests: } \\
\hline Panel v-statistic & $44.61347 *$ & Group $\rho$-statistic & $-45.98784 *$ \\
\hline Panel $\rho$-statistic & $-45.60563 *$ & Group PP-statistic & $-45.16044 *$ \\
\hline Panel PP-statistic & $-45.18914 *$ & Group ADF-statistic & $-8.11732 *$ \\
\hline Panel ADF-statistic & $-8.70563 *$ & & \\
\hline
\end{tabular}

Notes: Both the panel and group mean panel tests are distributed asymptotically as standard normal. Of the seven tests, the panel v-statistic is a one-sided test in which large positive values reject the null hypothesis of no cointegration. For the remaining test statistics, large negative values reject the null hypothesis of no cointegration. The $1 \%$ significance level denoted by “*”.

Table 6 displays the long-run parameter estimates via FMOLS. The results show that the impact of the BDI on financial asset prices and industrial production remains positive and statistical significant, regardless of the presence of an alternative indicator, i.e., the MSCI or oil prices. Although the new $\mathrm{a}_{1}$ estimates are relatively lower than those reported in Table 3, the relative merit of the BDI is shown to be higher vis-à-vis that of the two alternative indicators. In particular, Panel A reports the results when the MSCI index is included as the alternative leading indicator, while Panel $\mathrm{B}$ reports the corresponding results with oil prices as the alternative indicator. With respect to the results in Panel A, although there is consistency in the results across the two alternative indicators, the relative strength of the BDI index is apparent as the impact on industrial production $(0.138)$ is greater than the MSCI 
(0.059). The results remain robust, when, alternatively, oil prices are included as the additional indicator in the model, although the numerical strength of the BDI index is lower than in the case of the MSCI. Again, the strongest impact comes on industrial production, e.g., 0.129 versus 0.068 . Table 6 also reports joint $p$-values for the null hypothesis of $\mathrm{H}_{0}: \mathrm{a}_{1}=\mathrm{a}_{2}=0$. The empirical findings indicate that the two indicators complement each other in explaining financial asset prices and industrial production.

Table 6. Extended model FMOLS long-run estimates.

\begin{tabular}{|c|c|c|c|c|c|c|}
\hline \multicolumn{7}{|c|}{ Panel A: BDI and MSCI index } \\
\hline Variable & $\mathbf{a}_{1}$ & p-value & $\mathbf{a}_{2}$ & $p$-value & Adjusted-R ${ }^{2}$ & Joint $[p$-value $]$ \\
\hline $\mathrm{AP}^{\mathrm{STK}}$ & 0.107 & {$[0.00] *$} & 0.063 & {$[0.00] *$} & 0.68 & {$[0.00] *$} \\
\hline $\mathrm{AP}^{\mathrm{STB}}$ & 0.068 & {$[0.00] *$} & 0.030 & {$[0.00] *$} & 0.54 & {$[0.01] *$} \\
\hline $\mathrm{AP}^{\mathrm{LTB}}$ & 0.051 & {$[0.00] *$} & 0.026 & {$[0.00] *$} & 0.51 & {$[0.00] *$} \\
\hline $\mathrm{AP}^{\mathrm{COM}}$ & 0.085 & {$[0.00] *$} & 0.031 & {$[0.00] *$} & 0.49 & {$[0.01] *$} \\
\hline IP & 0.138 & {$[0.00] *$} & 0.059 & {$[0.00] *$} & 0.68 & {$[0.00] *$} \\
\hline \multicolumn{7}{|c|}{ Panel B: BDI and Oil Prices } \\
\hline Variable & $\mathbf{a}_{1}$ & p-value & $\mathbf{a}_{2}$ & p-value & Adjusted-R ${ }^{2}$ & Joint[p-value] \\
\hline $\mathrm{AP}^{\mathrm{STK}}$ & 0.096 & {$[0.00] *$} & 0.054 & {$[0.00] *$} & 0.69 & {$[0.00] *$} \\
\hline $\mathrm{AP}^{\mathrm{STB}}$ & 0.064 & {$[0.00] *$} & 0.043 & {$[0.00] *$} & 0.57 & {$[0.00] *$} \\
\hline $\mathrm{AP}^{\mathrm{LTB}}$ & 0.052 & {$[0.00] *$} & 0.036 & {$[0.00] *$} & 0.53 & {$[0.00] *$} \\
\hline $\mathrm{AP}^{\mathrm{COM}}$ & 0.073 & {$[0.00] *$} & 0.041 & {$[0.00] *$} & 0.57 & {$[0.00] *$} \\
\hline IP & 0.129 & {$[0.00] *$} & 0.068 & {$[0.00] *$} & 0.62 & {$[0.00] *$} \\
\hline
\end{tabular}

Notes: $a_{1}$ is the coefficient for BDI; $a_{2}$ represents the coefficient of either MSCI or OP; $p$-value is the probability value attached to the coefficient estimates $a_{1}$ and $a_{2}$; joint $p$-value is the joint probability value associated with the null hypothesis $\mathrm{a}_{1}=\mathrm{a}_{2}=0$; and adjusted $\mathrm{R}^{2}$ is the adjusted coefficient of determination. Probability values are in brackets with the $1 \%$ significance level denoted by “*”.

\subsection{Panel Causality in the Extended Models}

Given the extended models that include the MCSI and oil prices, we conduct causality testing associated with the respective panel error correction models to infer both the short-run and long-run causality between the respective financial asset prices, industrial production, and the relative causality merit between BDI and either MSCI or oil prices. Panels A through E in Table 7 report the causality results in regards to the inclusion of the MSCI alongside the BDI. The results indicate unidirectional causality from the $\mathrm{BDI}$ to $\mathrm{AP}^{\mathrm{STK}}, \mathrm{AP}^{\mathrm{LTB}}$, and $\mathrm{AP}^{\mathrm{COM}}$ in both the short-run and long-run; however, the MSCI does not Granger cause these particular financial asset markets in the short-run. Panel B reveals unidirectional causality in the case of the $\mathrm{BDI}$ and $\mathrm{MSCI}$ in both the short-run and long-run for $\mathrm{AP}^{\mathrm{STB}}$. In Panel E, the results reflect bidirectional causality between the BDI and MSCI with industrial production (IP). Panels $\mathrm{F}$ through $\mathrm{J}$ in Table 7 report the causality results with respect to the inclusion of oil prices alongside the BDI. Unlike the inclusion of the MSCI, oil prices (OP) and the BDI show unidirectional causality from both $\mathrm{OP}$ and $\mathrm{BDI}$ to $\mathrm{AP}^{\mathrm{STK}}, \mathrm{AP}^{\mathrm{STB}}, \mathrm{AP}^{\mathrm{LTB}}$, and $\mathrm{AP}^{\mathrm{COM}}$ in both the short-run and long-run, but bidirectional causality with respect to IP. 
Table 7. Extended panel causality test results.

\begin{tabular}{|c|c|c|c|c|c|}
\hline \multicolumn{6}{|c|}{ Panel A: AP ${ }^{\text {STK}}$-BDI -MSCI (6 lags) } \\
\hline \multicolumn{4}{|c|}{ Short-run } & Long-Run & Granger-Causality \\
\hline \multirow{3}{*}{$\Delta \mathrm{AP}^{\mathrm{STK}}$} & $\Delta \mathrm{AP}^{\mathrm{STK}}$ & $\Delta \mathrm{BDI}$ & $\triangle \mathrm{MSCI}$ & ECT & $\mathrm{BDI} \rightarrow \mathrm{AP}^{\mathrm{STK}}(\mathrm{SR}$ and $\mathrm{LR})$ \\
\hline & --- & 62.73 & 1.34 & -0.124 & \\
\hline & & {$[0.00] *$} & {$[0.59]$} & {$[0.00] *$} & \\
\hline \multirow[t]{2}{*}{$\Delta \mathrm{BDI}$} & 1.55 & --- & 0.61 & -0.084 & \\
\hline & {$[0.38]$} & {$[0.74]$} & {$[0.18]$} & & \\
\hline \multirow[t]{2}{*}{$\triangle \mathrm{MSCI}$} & 1.24 & 0.62 & --- & -0.011 & \\
\hline & {$[0.50]$} & {$[0.66]$} & & {$[0.61]$} & \\
\hline
\end{tabular}

Panel B: APSTB-BDI-MSCI (5 lags)

\begin{tabular}{|c|c|c|c|c|c|}
\hline \multicolumn{4}{|c|}{ Short-run } & Long-Run & Granger-Causality \\
\hline & $\Delta \mathrm{AP}^{\mathrm{STB}}$ & $\Delta \mathrm{BDI}$ & $\triangle \mathrm{MSCI}$ & ECT & $\mathrm{BDI} \rightarrow \mathrm{AP}^{\mathrm{STB}}(\mathrm{SR} / \mathrm{LR})$ \\
\hline \multirow[t]{2}{*}{$\Delta \mathrm{AP}^{\mathrm{STB}}$} & --- & 52.91 & 4.22 & -0.075 & $\mathrm{MSCI} \rightarrow \mathrm{AP}^{\mathrm{STB}}(\mathrm{SR} / \mathrm{LR})$ \\
\hline & & {$[0.00]^{*}$} & {$[0.11]$} & {$[0.00] *$} & \\
\hline \multirow[t]{2}{*}{$\Delta \mathrm{BDI}$} & 0.36 & --- & 0.71 & -0.059 & \\
\hline & {$[0.75]$} & {$[0.58]$} & & {$[0.52]$} & \\
\hline \multirow[t]{2}{*}{$\Delta \mathrm{MSCI}$} & 3.18 & 0.57 & --- & -0.036 & \\
\hline & [0.19] & {$[0.62]$} & & [0.69] & \\
\hline
\end{tabular}

Panel C: APLTB-BDI-MSCI (6 lags)

\begin{tabular}{|c|c|c|c|c|c|}
\hline \multicolumn{4}{|c|}{ Short-run } & Long-Run & \multirow{2}{*}{$\begin{array}{c}\text { Granger-Causality } \\
\mathrm{BDI} \rightarrow \mathrm{AP}^{\mathrm{LTB}}(\mathrm{SR} / \mathrm{LR})\end{array}$} \\
\hline & $\Delta \mathrm{AP}^{\mathrm{LTB}}$ & $\Delta \mathrm{BDI}$ & $\Delta \mathrm{MSCI}$ & ECT & \\
\hline \multirow[t]{2}{*}{$\Delta \mathrm{AP}^{\mathrm{LTB}}$} & --- & 48.91 & 1.36 & -0.125 & \\
\hline & & {$[0.00] *$} & {$[0.40]$} & {$[0.00] *$} & \\
\hline \multirow[t]{2}{*}{$\Delta \mathrm{BDI}$} & 0.56 & --- & 0.71 & -0.048 & \\
\hline & {$[0.71]$} & & [0.69] & {$[0.57]$} & \\
\hline \multirow[t]{2}{*}{$\triangle \mathrm{MSCI}$} & 0.74 & 1.44 & --- & -0.059 & \\
\hline & {$[0.61]$} & {$[0.41]$} & & {$[0.48]$} & \\
\hline
\end{tabular}

Panel D: APCOM-BDI-MSCI (7 lags)

\begin{tabular}{|c|c|c|c|c|c|}
\hline \multicolumn{4}{|c|}{ Short-run } & Long-Run & \multirow{2}{*}{$\begin{array}{c}\text { Granger-Causality } \\
\mathrm{BDI} \rightarrow \mathrm{AP}^{\mathrm{COM}}(\mathrm{SR} / \mathrm{LR})\end{array}$} \\
\hline \multirow{3}{*}{$\Delta \mathrm{AP}^{\mathrm{COM}}$} & $\Delta \mathrm{AP}^{\mathrm{COM}}$ & $\Delta \mathrm{BDI}$ & $\Delta \mathrm{MSCI}$ & ECT & \\
\hline & --- & 68.71 & 1.34 & -0.142 & \\
\hline & & {$[0.00] *$} & {$[0.21]$} & {$[0.00] *$} & \\
\hline \multirow[t]{2}{*}{$\Delta \mathrm{BDI}$} & 0.73 & --- & 1.64 & -0.071 & \\
\hline & {$[0.52]$} & & {$[0.21]$} & {$[0.22]$} & \\
\hline \multirow[t]{2}{*}{$\triangle \mathrm{MSCI}$} & 0.63 & 0.93 & -- & -0.037 & \\
\hline & [0.69] & {$[0.28]$} & & {$[0.42]$} & \\
\hline \multicolumn{6}{|c|}{ Panel E: IP-BDI-MSCI (6 lags) } \\
\hline \multicolumn{4}{|c|}{ Short-run } & Long-Run & Granger-Causality \\
\hline \multirow{3}{*}{$\Delta \mathrm{IP}$} & $\Delta \mathrm{IP}$ & $\Delta \mathrm{BDI}$ & $\triangle \mathrm{MSCI}$ & ECT & $\mathrm{BDI} \rightarrow \mathrm{IP}(\mathrm{SR} / \mathrm{LR})$ \\
\hline & --- & 63.19 & 31.82 & -0.176 & $\mathrm{MSCI} \leftrightarrow \mathrm{IP}(\mathrm{SR} / \mathrm{LR})$ \\
\hline & {$[0.00]^{*}$} & {$[0.00] *$} & {$[0.00] *$} & & \\
\hline \multirow[t]{2}{*}{$\Delta \mathrm{BDI}$} & 46.11 & --- & 1.18 & -0.146 & \\
\hline & {$[0.00]^{*}$} & {$[0.59]$} & {$[0.00] *$} & & \\
\hline \multirow[t]{2}{*}{$\Delta \mathrm{MSCI}$} & 49.94 & 0.86 & --- & -0.095 & \\
\hline & {$[0.00]^{*}$} & {$[0.68]$} & & {$[0.00] *$} & \\
\hline
\end{tabular}


Table 7. Cont.

\begin{tabular}{|c|c|c|c|c|c|}
\hline \multicolumn{6}{|c|}{ Panel F: AP ${ }^{\text {STK}}$-BDI-OP (7 lags) } \\
\hline \multicolumn{4}{|c|}{ Short-run } & Long-Run & Granger-Causality \\
\hline \multirow{3}{*}{$\Delta \mathrm{AP}^{\mathrm{STK}}$} & $\Delta \mathrm{AP}^{\mathrm{STK}}$ & $\Delta \mathrm{BDI}$ & $\Delta \mathrm{MSCI}$ & ECT & $\mathrm{BDI} \rightarrow \mathrm{AP}^{\mathrm{STK}}(\mathrm{SR} / \mathrm{LR})$ \\
\hline & --- & 53.83 & 14.32 & -0.105 & $\mathrm{OP} \rightarrow \mathrm{AP}^{\mathrm{STK}}(\mathrm{SR} / \mathrm{LR})$ \\
\hline & & {$[0.00] *$} & {$[0.07] *$} & {$[0.00]^{*}$} & \\
\hline \multirow{2}{*}{$\Delta \mathrm{BDI}$} & 1.63 & --- & 2.04 & -0.066 & \\
\hline & {$[0.36]$} & {$[0.24]$} & {$[0.14]$} & & \\
\hline \multirow[t]{2}{*}{$\Delta \mathrm{OP}$} & 0.98 & 0.85 & --- & -0.024 & \\
\hline & {$[0.71]$} & {$[0.82]$} & & {$[0.32]$} & \\
\hline
\end{tabular}

Panel G: AP ${ }^{\text {STB }}$-BDI-OP (6 lags)

\begin{tabular}{cccccc}
\hline & \multicolumn{2}{c}{ Short-run } & & Long-Run & Granger-Causality \\
\hline \multirow{4}{*}{$\Delta \mathrm{AP}^{\mathrm{STB}}$} & $\Delta \mathrm{AP}^{\mathrm{STK}}$ & $\Delta \mathrm{BDI}$ & $\Delta \mathrm{MSCI}$ & $\mathrm{ECT}$ & $\mathrm{BDI} \rightarrow \mathrm{AP}^{\mathrm{STK}}(\mathrm{SR} / \mathrm{LR})$ \\
& -- & 56.71 & 10.96 & -0.102 & $\mathrm{OP} \rightarrow \mathrm{AP}^{\mathrm{STB}}(\mathrm{SR} / \mathrm{LR})$ \\
$\Delta \mathrm{BDI}$ & 0.61 & {$[0.00]$} & {$[0.00]^{*}$} & {$[0.00]^{*}$} & \\
& {$[0.68]$} & --- & 0.36 & -0.053 & \\
$\Delta \mathrm{OP}$ & 1.22 & 0.84 & {$[0.80]$} & {$[0.15]$} & \\
& {$[0.39]$} & {$[0.45]$} & -- & -0.038 & \\
\hline
\end{tabular}

Panel H: APLTB-BDI-OP (6 lags)

\begin{tabular}{|c|c|c|c|c|c|}
\hline \multicolumn{4}{|c|}{ Short-run } & Long-Run & Granger-Causality \\
\hline \multirow{3}{*}{$\Delta \mathrm{AP}^{\mathrm{LTB}}$} & $\triangle \mathrm{AP}^{\mathrm{LTB}}$ & $\Delta \mathrm{BDI}$ & $\Delta \mathrm{MSCI}$ & ECT & $\mathrm{BDI} \rightarrow \mathrm{AP}^{\mathrm{STK}}(\mathrm{SR} / \mathrm{LR})$ \\
\hline & --- & 57.84 & 11.66 & -0.112 & $\mathrm{OP} \rightarrow \mathrm{AP}^{\mathrm{LTB}}(\mathrm{SR} / \mathrm{LR})$ \\
\hline & & {$[0.00]^{*}$} & {$[0.06] * *$} & {$[0.00] *$} & \\
\hline \multirow[t]{2}{*}{$\Delta \mathrm{BDI}$} & 0.58 & --- & 0.52 & -0.040 & \\
\hline & {$[0.61]$} & & {$[0.56]$} & {$[0.49]$} & \\
\hline \multirow[t]{2}{*}{$\Delta \mathrm{OP}$} & 2.64 & 2.27 & --- & -0.058 & \\
\hline & {$[0.24]$} & {$[0.26]$} & & {$[0.30]$} & \\
\hline
\end{tabular}

Panel I: APCOM-BDI-OP (6 lags)

\begin{tabular}{|c|c|c|c|c|c|}
\hline \multicolumn{4}{|c|}{ Short-run } & Long-Run & Granger-Causality \\
\hline \multirow{3}{*}{$\triangle \mathrm{AP}^{\mathrm{COM}}$} & $\Delta \mathrm{AP}^{\mathrm{COM}}$ & $\Delta \mathrm{BDI}$ & $\Delta \mathrm{MSCI}$ & ECT & $\mathrm{BDI} \rightarrow \mathrm{AP}^{\mathrm{STK}}(\mathrm{SR} / \mathrm{LR})$ \\
\hline & --- & 50.18 & 5.62 & -0.158 & $\mathrm{OP} \rightarrow \mathrm{AP}^{\mathrm{COM}}(\mathrm{SR} / \mathrm{LR})$ \\
\hline & & {$[0.00] *$} & {$[0.09] * * *$} & {$[0.00] *$} & \\
\hline \multirow[t]{2}{*}{$\Delta \mathrm{BDI}$} & 0.81 & --- & 2.96 & -0.074 & \\
\hline & {$[0.45]$} & & [0.16] & {$[0.31]$} & \\
\hline \multirow[t]{2}{*}{$\Delta \mathrm{OP}$} & 0.52 & 0.84 & --- & -0.048 & \\
\hline & {$[0.77]$} & {$[0.39]$} & & {$[0.27]$} & \\
\hline \multicolumn{6}{|c|}{ Panel J: IP-BDI-OP (7 lags) } \\
\hline \multicolumn{4}{|c|}{ Short-run } & Long-Run & Granger-Causality \\
\hline \multirow{3}{*}{$\Delta \mathrm{IP}$} & $\Delta \mathrm{IP}$ & $\Delta \mathrm{BDI}$ & $\Delta \mathrm{MSCI}$ & ECT & $\mathrm{BDI} \leftrightarrow \mathrm{IP}(\mathrm{SR} / \mathrm{LR})$ \\
\hline & --- & 73.04 & 40.01 & -0.186 & $\mathrm{OP} \leftrightarrow \mathrm{IP}(\mathrm{SR} / \mathrm{LR})$ \\
\hline & & {$[0.00]^{*}$} & {$[0.00] *$} & {$[0.00] *$} & \\
\hline \multirow[t]{2}{*}{$\Delta \mathrm{BDI}$} & 38.51 & --- & 1.25 & -0.161 & \\
\hline & {$[0.00] *$} & & {$[0.48]$} & {$[0.00] *$} & \\
\hline \multirow[t]{2}{*}{$\triangle \mathrm{OP}$} & 46.45 & 1.27 & --- & -0.135 & \\
\hline & {$[0.00] *$} & [0.62] & & {$[0.00] *$} & \\
\hline
\end{tabular}

Notes: Wald F-statistics reported with respect to short-run changes in the independent variables. ECT represents the coefficient of the error correction term. Probability values are in brackets with the $1 \%$ and $10 \%$ significant levels denoted by “*” and “***”, respectively. SR represents the short-run and LR the long-run. 


\subsection{Out-of-Sample Predictability of the BDI}

To assess the out-of-sample prediction ability of the BDI we use a rolling regression methodology based on the error correction models presented. That is, each model is first estimated using data up until the first forecasting period. The forecasts are generated at 1, 10, 30, 180, and 365 days (actually, the period of 365 days includes 259 observations. The same also holds for the remaining time periods). In the next step, the estimation period is rolled forward by one day, keeping the total length of the estimation period fixed. New forecasts are then generated at 1, 10, 30, 180 and 365 days. The root mean square error (RMSE), the mean absolute error (MAE), and the Theil inequality coefficient (THEIL) are used to evaluate the out-of-sample forecasting performance of the respective error correction models.

We begin by first considering a model in which only the BDI is shown to be the key indicator against the two models in which the other two alternative indicators, i.e., the MSCI and oil prices, are used. As mentioned earlier, the estimation period is from 1985:1 to 2011:365, while the forecasting horizons are noted as follows: (i) 2012:1 to 2012:2; (ii) 2012:1 to 2012:10; (iii) 2012:1 to 2012:30; (iv) 2012:1 to 2012:180; and (v) 2012:1 to 2012:365. We, thus, compare the out-of-sample forecasted values with the actual values. The results, reported in Table 8 , show that though the forecasting performance in all three alternative models deteriorates as the forecast horizon is lengthened, the model with the inclusion of the BDI performs better than the model with the other two alternative indicators, at all horizons. Therefore, the forecasting experiment confirms the Granger causality results reported above as well as BDI's predictive ability and its in-sample information content as an indicator for financial asset prices and industrial production.

\section{Conclusions}

This exploratory empirical study analyzes the role of the Baltic Dry Index (BDI) in explaining the behavior of financial asset prices and industrial production. By using a panel data framework for financial asset prices and industrial production over the period 1985-2012, the long-run empirical analysis conducted for both in-sample and out-of-sample confirms the role of the BDI as a useful indicator. Furthermore, the empirical findings demonstrate the robustness of the BDI's role in light of the presence of alternative indicators, the MSCI and oil prices. Overall, this study demonstrates the relevance of the BDI as an indicator that captures the variations across financial asset markets and the macroeconomy. These findings support the claim of the close relationship between the cost of shipping raw materials and the production of intermediate and final goods in that the demand for commodities and, therefore, economic activity, follows movements in the BDI. This relationship of the BDI to the real economy also impacts financial asset markets as well. Our results are in contrast with those reached by Alizadeh and Muradoglu [21] in a sense that they provide support to the efficiency hypothesis, i.e., information about the BDI changes are shortly and fully reflected in asset prices, since traders and investors in those markets can easily and at no cost observe BDI information and, thus, they can rapidly reach rational investing decisions. Predictability is not only apparent on a short-term basis, but also it is persistent at longer horizons. 
Table 8. Forecasting metrics.

\begin{tabular}{|c|c|c|c|c|c|c|c|c|c|}
\hline \multicolumn{10}{|c|}{ Panel A: Forecast Summary Measures } \\
\hline Horizon & RMSE & MAE & THEIL & RMSE & MAE & THEIL & RMSE & MAE & THEIL \\
\hline & \multicolumn{3}{|c|}{$\mathrm{AP}^{\mathrm{STK}}$-BDI } & \multicolumn{3}{|c|}{$\mathrm{AP}^{\mathrm{STK}}$-MSCI } & \multicolumn{3}{|c|}{$\mathrm{AP}^{\mathrm{STK}}-\mathrm{OP}$} \\
\hline 1 & 4.906 & 5.783 & 0.268 & 4.961 & 5.908 & 0.291 & 4.937 & 5.855 & 0.285 \\
\hline 10 & 5.024 & 5.951 & 0.289 & 5.461 & 6.099 & 0.296 & 5.286 & 6.048 & 0.292 \\
\hline 30 & 5.508 & 6.185 & 0.314 & 5.677 & 6.439 & 0.325 & 5.854 & 6.290 & 0.321 \\
\hline 180 & 5.894 & 6.507 & 0.358 & 5.949 & 6.638 & 0.370 & 5.898 & 6.632 & 0.369 \\
\hline 365 & 6.105 & 6.884 & 0.392 & 6.337 & 6.995 & 0.428 & 6.218 & 6.901 & 0.405 \\
\hline \multicolumn{10}{|c|}{ Panel B: Forecast Summary Measures } \\
\hline Horizon & RMSE & MAE & THEIL & RMSE & MAE & THEIL & RMSE & MAE & THEIL \\
\hline & \multicolumn{3}{|c|}{$\mathrm{AP}^{\mathrm{STB}}$-BDI } & \multicolumn{3}{|c|}{$\mathrm{AP}^{\mathrm{STB}}$-MSCI } & \multicolumn{3}{|c|}{$\mathrm{AP}^{\mathrm{STB}}-\mathrm{OP}$} \\
\hline 1 & 5.248 & 5.409 & 0.286 & 5.619 & 5.731 & 0.310 & 5.438 & 5.629 & 0.298 \\
\hline 10 & 5.546 & 5.817 & 0.315 & 5.826 & 5.905 & 0.337 & 5.632 & 5.844 & 0.326 \\
\hline 30 & 5.915 & 6.236 & 0.361 & 6.117 & 6.448 & 0.389 & 6.026 & 6.372 & 0.375 \\
\hline 180 & 6.274 & 6.548 & 0.390 & 6.548 & 6.825 & 0.428 & 6.430 & 6.669 & 0.408 \\
\hline 365 & 6.637 & 6.871 & 0.418 & 6.836 & 6.995 & 0.457 & 6.744 & 6.903 & 0.425 \\
\hline \multicolumn{10}{|c|}{ Panel C: Forecast Summary Measures } \\
\hline Horizon & RMSE & MAE & THEIL & RMSE & MAE & THEIL & RMSE & MAE & THEIL \\
\hline & \multicolumn{3}{|c|}{$\mathrm{AP}^{\mathrm{LTB}}-\mathrm{BDI}$} & \multicolumn{3}{|c|}{$\mathrm{AP}^{\mathrm{LTB}}$-MSCI } & \multicolumn{3}{|c|}{$\mathrm{AP}^{\mathrm{LTB}}-\mathrm{OP}$} \\
\hline 1 & 5.127 & 5.326 & 0.295 & 5.548 & 5.912 & 0.348 & 5.335 & 5.618 & 0.313 \\
\hline 10 & 5.548 & 5.704 & 0.328 & 5.983 & 6.109 & 0.381 & 5.711 & 5.923 & 0.357 \\
\hline 30 & 5.905 & 6.128 & 0.381 & 6.326 & 6.576 & 0.419 & 6.224 & 6.348 & 0.398 \\
\hline 180 & 6.327 & 6.683 & 0.399 & 6.874 & 6.905 & 0.439 & 6.615 & 6.904 & 0.418 \\
\hline 365 & 6.629 & 6.972 & 0.442 & 7.318 & 7.459 & 0.485 & 6.983 & 7.302 & 0.466 \\
\hline \multicolumn{10}{|c|}{ Panel D: Forecast Summary Measures } \\
\hline Horizon & RMSE & MAE & THEIL & RMSE & MAE & THEIL & RMSE & MAE & THEIL \\
\hline & \multicolumn{3}{|c|}{$\mathrm{AP}^{\mathrm{COM}}$-BDI } & \multicolumn{3}{|c|}{$\mathrm{AP}^{\mathrm{COM}}-\mathrm{MSCI}$} & \multicolumn{3}{|c|}{$\mathrm{AP}^{\mathrm{COM}}-\mathrm{OP}$} \\
\hline 1 & 6.137 & 6.837 & 0.314 & 6.663 & 7.358 & 0.346 & 6.328 & 7.119 & 0.322 \\
\hline 10 & 6.528 & 7.271 & 0.355 & 7.093 & 7.693 & 0.392 & 6.771 & 7.348 & 0.360 \\
\hline 30 & 6.944 & 7.561 & 0.387 & 7.452 & 7.984 & 0.425 & 7.216 & 7.709 & 0.398 \\
\hline 180 & 7.328 & 7.907 & 0.422 & 7.651 & 8.436 & 0.492 & 7.561 & 8.225 & 0.473 \\
\hline 365 & 7.673 & 8.124 & 0.461 & 8.046 & 8.562 & 0.536 & 7.842 & 8.337 & 0.491 \\
\hline \multicolumn{10}{|c|}{ Panel E: Forecast Summary Measures } \\
\hline \multirow[t]{2}{*}{ Horizon } & RMSE & MAE & THEIL & RMSE & MAE & THEIL & RMSE & MAE & THEIL \\
\hline & \multicolumn{3}{|c|}{ IP-BDI } & \multicolumn{3}{|c|}{ IP-MSCI } & \multicolumn{3}{|c|}{ IP-OP } \\
\hline 1 & 5.128 & 5.674 & 0.271 & 5.558 & 5.903 & 0.341 & 5.325 & 5.751 & 0.294 \\
\hline 10 & 5.443 & 5.935 & 0.316 & 5.836 & 6.438 & 0.372 & 5.661 & 6.264 & 0.366 \\
\hline 30 & 5.893 & 6.438 & 0.359 & 6.418 & 6.922 & 0.397 & 6.109 & 6.614 & 0.385 \\
\hline 180 & 6.436 & 6.951 & 0.402 & 6.952 & 7.513 & 0.448 & 6.716 & 7.228 & 0.439 \\
\hline 365 & 6.710 & 7.358 & 0.472 & 7.095 & 7.774 & 0.496 & 6.911 & 7.592 & 0.481 \\
\hline
\end{tabular}

\section{Acknowledgments}

The authors wish to thank two referees of this journal for their constructive comments that improves the picture of the first draft of the paper. Needless to say, errors and omissions are our responsibility. 


\section{Conflict of Interest}

The authors declare no conflict of interest.

\section{References}

1. Stock, J.H.; Watson, M.W. Business Cycle Fluctuations in U.S. Macroeconomic Time Series; NBER Working Paper No. 6528; National Bureau of Economic Research: Cambridge, MA, USA, 1998.

2. Stock, J.H.; Watson, M.W. Forecasting inflation. J. Monet. Econ. 1999, 44, 293-335.

3. Cecchetti, S.G.; Chu, R.S.; Steindel, C. The unreliability of inflation indicators. Curr. Issues Econ. Financ. 2000, 6, 1-6.

4. Camba-Mendez, G.; Kapetanios, G.; Smith, R.J.; Weale, M.R. An automatic leading indicator of economic activity: Forecasting GDP growth for European countries. Econ. J. 2001, 4, S56-S90.

5. Fama, E. Stock returns, expected returns, and real activity. J. Fin. 1990, 45, 1089-1108.

6. Cochrane, J. Production-based asset pricing and the link between stock returns and economic fluctuations. J. Fin. 1991, 46, 209-237.

7. Restoy, F.; Rockinger, G. On stock market returns and returns on investment. J. Fin. 1994, 49, 543-556.

8. Boldrin, M.; Christiano, L.; Fisher, J. Habit persistence, asset returns, and the business cycle. Am. Econ. Rev. 2001, 91, 149-166.

9. Estrella, A.; Rodrigues, A.P.; Schich, S. How stable is the predictive power of the yield curve? Evidence from Germany and the United States. Rev. Econ. Stat. 2003, 85, 629-644.

10. Vassalou, M. News related to future GDP growth as a risk factor in equity returns. J. Fin. Econ. 2003, 68, 47-73.

11. Duarte, A.; Venetis, I.A.; Paya, I. Predicting real growth and the probability of recession in the Euro-area using the yield spread. Int. J. Forecast. 2005, 21, 261-277.

12. Hong, H.; Torous, W.; Valkanov, R. Do industries lead stock markets? J. Fin. Econ. 2007, 83, 367-396.

13. Clements, M.; Galvao, A.B. Macroeconomic forecasting with mixed-frequency data: Forecasting output growth in the United States. J. Bus. Econ. Stat. 2008, 26, 546-554.

14. Cooper, I.; Priestley, R. Time-varying risk premium and the output-gap. Rev. Fin. Stud. 2009, 22, 2801-2833.

15. Marcellino, M.; Schumacher, C. Factor-MIDAS for now- and forecasting with ragged-edge data: A model comparison for German GDP. Oxf. Bull. Econ. Stat. 2010, 72, 518-550.

16. Hamilton, J. What is an oil shock? J. Econ. 2003, 113, 363-398.

17. Killian, L. The economic effects of energy price shocks. J. Econ. Lit. 2008, 46, 871-909.

18. Killian, L.; Park, C. The impact of oil price shocks on the U.S. stock market. Int. Econ. Rev. 2009, 50, 1267-1287.

19. Stopford, M. Maritime Economics; Routledge: New York, NY, USA, 2009.

20. Bakshi, G.S.; Panayotov, G.; Skoulakis, G. The Baltic Dry Index as a predictor of global stock returns, commodity returns, and global economic activity. Available online: http://papers.ssrn.com/ sol3/papers.cfm?abstract_id=1747345 (accessed on 10 April 2013). 
21. Alizadeh, A.H.; Muradoglu, G. Stock market returns and shipping freight market information: Yet another puzzle! Available online: http://papers.ssrn.com/sol3/papers.cfm?abstract_id=1905590 (accessed on 11 April 2013).

22. Levin, A.; Lin, C.F. Unit Root Tests in Panel Data: New Results; Discussion Paper No. 56; University of California at San Diego (UCSD): La Jolla, CA, USA, 1993.

23. Harris, R.D.F.; Tzavalis, E. Inference for unit roots in dynamic panels where the time dimension is fixed. J. Econ. 1999, 91, 201-226.

24. Maddala, G.S.; Wu, S. A comparative study of unit root tests with panel data and a new simple test. Oxf. Bull. Econ. Stat. 1999, 61, 631-652.

25. Breitung, J. The Local Power of Some Unit Root Tests for Panel Data. In Advances in Econometrics: Nonstationary Panels, Cointegration in Panels and Dynamic Panels; Baltagi, B., Fomby, T.B., Hill, R.C., Eds.; JAI: Amsterdam, The Netherlands, 2000; Volume 15, pp. 161-178.

26. Dickey, D.A.; Fuller, W.A. Distribution of the estimators for autoregressive time series with a unit root. Econometrica 1981, 49, 1057-1072.

27. Park, H.; Fuller, W. Alternative estimators and unit root tests for the autoregressive process. J. Time Ser. Anal. 1995, 16, 415-429.

28. Elliot, G.; Rothenberg, T.J.; Stock, J.H. Efficient tests for an autoregressive unit root. Econometrica 1996, 64, 813-836.

29. Pedroni, P. Purchasing power parity tests in cointegrated panels. Rev. Econ. Stat. 2001, 83, 727-731.

30. Pedroni, P. Critical values for cointegration tests in heterogeneous panels with multiple regressors. Oxf. Bull. Econ. Stat. 1999, 61, 653-670.

31. Pedroni, P. Fully modified OLS for heterogeneous cointegrated panels. Adv. Econ. 2000, 15, 93-130.

32. French, K.R.G.; Schwert, G.W.; Stambaugh, R.F. Expected stock returns and volatility. J. Fin. Econ. 1987, 3, 3-29.

33. Schwert, G.W. Anomalies and Market Efficiency. In The Handbook of the Economics of Finance: Financial Markets and Asset Pricing; Constantinides, G.M., Harris, M., Stulz, R., Eds.; Elsevier: Amsterdam, The Netherlands, 2003.

34. Campell, J.; Thompson, S. Predicting excess stock returns out of sample: Can anything beat the historical average? Rev. Fin. Stud. 2008, 21, 1509-1531.

35. Goyal, A.; Welch, I. A comprehensive look at the empirical performance of equity premium prediction. Rev. Fin. Stud. 2008, 21, 1455-1508.

36. Rangvid, J. Output and expected returns. J. Fin. Econ. 2006, 81, 595-624.

37. Bessembinder, H.; Chan, K. Time-varying risk premia and forecastable returns in futures markets. J. Fin. Econ. 1992, 32, 169-193.

38. Gorton, G.; Hayashi, F.; Rouwenhorst, G. The Fundamentals of Commodity Futures Returns; Working Paper 2008; Department of Economics, Yale University: New Haven, CT, USA, 2008.

39. Harvey, C.R. The world price of covariance risk. J. Fin. 1991, 46, 111-157.

40. Harvey, C.R. Predictable risk and returns in emerging markets. Rev. Fin. Stud. 1995, 8, 773-816.

41. Jones, C.; Kaul, G. Oil and the stock markets. J. Fin. 1996, 51, 463-491.

42. Ang, A.; Bekaert, G. Stock return predictability. Is it there? Rev. Fin. Stud. 2007, 20, 651-707. 
43. Sorensen, L.Q. Oil price shocks and stock return predictability. Available online: http://ssrn.com/abstract=1341013 (accessed on 13 April 2013).

44. Hjalmarsson, E. Predicting global stock returns. J. Fin. Quant. Anal. 2010, 45, 49-80.

\section{Data Appendix}

Stock Returns $\left(A P^{S T K}\right)$ :

United States (S\&P500), United Kingdom (FTSE100), Japan (NIKKEI225), Canada (S\&P/TSX Composite), Germany (DAX), France (CAC40), and Italy (S\&P/MIB Index). Source: Datastream.

Short-Term Bonds $\left(A P^{S T B}\right)$ :

3-month Canadian Government Bonds, 3-month French Treasury Bills, 3-month German Bubill Government Bonds, 3-month Italian Treasury Bills, 3-month U.K. Government Bonds, Japanese Treasury Discount Bills, 3-month U.S. Generic government bonds. Source: Datastream.

Long-Term Bonds $\left(A P^{L T B}\right)$ :

10-year Canadian Government Bonds, 10-year French Government Bonds, 10-year German Government Bonds, 10-year Italian Government Bonds, Japanese Government Bonds, 10-year U.K. Government Bonds, 10-year U.S. Generic Government Bonds. Source: Datastream.

Commodity index $\left(A P^{C O M}\right)$ :

The Dow Jones-UBS Commodity Index, which is a broadly diversified index that allows investors to track commodity futures. Source: Bloomberg.

Industrial Production (IP):

U.S. Industrial Production $(2007=100)$, STCA Canadian Industrial Production $(2007=100)$, Japanese Industrial Production $(2005=100)$, French Industrial Production $(2007=100)$, Italian Industrial Production $(2007=100)$, U.K. Industrial Production $(2005=100)$, German Industrial Production $(2007=100)$. Source: Datastream.

Oil Prices (OP):

Oil prices are defined by the spot price of West Texas Intermediate crude oil. West Texas Intermediate (WTI) is a type of crude oil used as a benchmark in oil pricing and the underlying commodity of the New York Mercantile Exchange's oil futures contracts. Source: Datastream.

Baltic Dry Index (BDI):

The Baltic Dry Index is a daily average of prices to ship raw materials. It represents the cost paid by an end customer to have a shipping company transport raw materials across seas on the Baltic Exchange, the global marketplace for brokering shipping contracts. Source: Bloomberg. 
MCSI World Index (MSCI):

The MSCI captures large and mid cap representation across 24 Developed Markets (DM) countries. With 1,608 constituents, the index covers approximately $85 \%$ of the free float-adjusted market capitalization in each country. Source: Bloomberg.

(C) 2013 by the authors; licensee MDPI, Basel, Switzerland. This article is an open access article distributed under the terms and conditions of the Creative Commons Attribution license (http://creativecommons.org/licenses/by/3.0/). 